\title{
The institutional thickness of an inner periphery in the cross-border region between Central Bohemia and Eastern Bohemia
}

\author{
MAREK KOMÁREK, PAVEL CHROMÝ
}

Charles University, Faculty of Science, Department of Social Geography and Regional Development, Prague, Czechia; e-mail: marek.komarek@natur.cuni.cz,pavel.chromy@natur.cuni.cz

ABSTRACT The paper aims to analyze the "soft" factors of local development and to understand the nature of the socio-economic differences between municipalities in an inner periphery in Bohemia. The partial goals are to explain which internal conditions are conductive to the formation of these ties of cooperation, to reveal which power structures are involved in the ties of cooperation, and to assess the direction of these interactions. The conclusions are formulated and discussed in relation to the concept of institutional thickness. Our research confirmed the key differentiating role of mayors in local interactions and the importance of administrative boundaries - especially boundaries of self-government regions. These boundaries had the effect of constraining the formation of formal and informal relations between actors in territorial development. The research also provides evidence of the continued existence of links between municipalities that were formed during the communist period. The data come from the author's field survey among the mayors.

KEY WORDS institutional thickness - inner periphery - local development - municipalities Czechia

KOMÁREK, M., CHROMÝ, P. (2020): The institutional thickness of an inner periphery in the crossborder region between Central Bohemia and Eastern Bohemia. Geografie, 125, 4, 423-446.

https://doi.org/10.37040/geografie2020125040423

Received April 2020, accepted July 2020.

(C) Česká geografická společnost, z. s., 2020 


\section{Introduction}

Inequalities naturally arise between regions in the course of their development. The implication of this is that some areas are more successful, while others (problem regions) are less so (Friedmann 1972; Havlíček, Chromý 2001; Marada et. al. 2006; Vaishar 2006; Hampl, Dostál, Drbohlav 2007; Siwek 2012; Kuhn 2015; Pociute-Sereikiene 2019). With deepening European integration, such 'problem regions' very quickly came to include regions with structural problems and an ineffectively structured local economy inherited from the era of central planning (Dostál, Hampl 2002) and peripheral regions located on the national border (e.g. Chromý 2003; Chromý, Skála 2010). However, inner peripheries, which are usually located on the borders between administrative units within the country, also fall into this category (Musil 1988; Jančák et. al. 2006, 2008; Musil, Müller 2008; Jakešová, Vaishar 2012). According to Blažek and Uhlíř (2011), inequalities and the areas that then come to be identified as a core or a periphery arise as the result of various factors, actors, mechanisms, and other conditions of regional development (Blažek 2005; Hampl 2007; Hampl, Blažek, Žížalová 2008). Different places are usually situated within relatively similar 'external frames' of development, and differences in their socio-economic performance are thus due to 'internal factors' (this means not just natural or economic resources, but also the increasingly significant factor of socio-cultural environment - i.e. the regional 'milieu'). Concepts that consider the quality of a particular environment solely on the basis of 'soft' characteristics associated with endogenous resources, manifested as the mobilisation of the various internal resources of a place, are currently regarded as the primary measure of a region's competitiveness in a globalised world (Blažek 2012). One such concept is the concept of institutional thickness (Amin, Thrift 1994), which also seeks to synthesise the whole range of 'soft' factors that exist (including social and human capital, which has been much discussed in the literature in recent decades). This paper uses the concept of institutional thickness as its primary explanatory framework (as it also was in Komárek 2017) for understanding the nature of social and economic differences between municipalities in the area of an inner periphery.

Municipal mayors undeniably play a key role in the development of local peripheral areas. Since the demise of the political 'central-place system' of municipalities following the collapse of the communist regime, Czechia has been left with a very dense network of municipal authorities. On average there are just several dozen inhabitants per rural municipality in the largely disintegrated Czech system (Novák, Netrdová 2011), and mayors are figures that serve as a strongly differentiating factor, depending on their skills and the opportunities and the pool of contacts they create. Bernard et al. (2011), for example, have discussed how mayors can have an effect on local development. Some mayors are skilled at 
mobilising and making things happen and introducing (local) strategies to solve problems and they thereby become leaders (Sotarauta 2005). In addition to the presence of capable actors, another factor crucial to the successful development of a larger region is that there is strong interaction and cooperation between these actors - on the individual level and via platforms such as voluntary associations of municipalities, local action groups (LAG), and even the now officially defunct structures that were formed during the period of the 'central-place system' of residential settlements (which in some places is still informally utilised to organise meetings among mayors and oftentimes to address local problems). It is good for a larger region to establish a shared awareness and a positive atmosphere within that region, to set out a common vision and similar goals, and to configure their power structures. These characteristics are the basic building blocks of the concept of institutional thickness (Amin, Thrift 1994). Mayors along with representatives of local associations (who are however often dependent on municipal funding) are thus unrivalled among the actors involved in development in terms of both their density and the even pattern of their spatial distribution across Czech rural areas (Perlín, Hupková 2010). It can therefore be assumed that municipal authorities and mayors are key institutions in the creation of institutional thickness in rural areas.

There are significant differences between mayors of small rural municipalities. The differences in the way local self-governments function have been summarised, for example, in Illner $(1992,1996)$ and Bernard et al. (2011). The smaller the size of the municipality, the greater the share of mayors who are not freed up from employment in order to devote themselves full time to the job of being mayor, and this, particularly for reasons of time, is an enormous obstacle in the path to forging ties beyond the borders of the municipality and therefore also to the development of institutional thickness. These 'part-time' mayors thus usually cannot become local leaders, even when the other conditions are right for them becoming so. In better cases, part-time mayors are at least able to maintain passive inter-municipal ties by drawing on the advice (about performing their function) of full-time mayors in surrounding municipalities. But in the case where no inter-municipal relations are maintained, this can have a negative effect on the institutional thickness of the wider vicinity and can put other potential actors in local development at a disadvantage with respect to their involvement in the wider community. In should also be noted in this connection that inter-municipal relations are much more difficult to build when municipalities are located in direct proximity to the administrative borders of a higher administrative unit - especially the self-government regions (of which there are 14 in Czechia). However, a similar barrier to the formation of inter-municipal ties may be represented by the administrative border of what are known as 'municipalities with extended powers' (of which there are 206 in Czechia, hereinafter MEP) or by the administrative border of the district covered 
by a 'municipality with an authorised municipal office' (of which there are 393 in the Czechia, hereinafter AMO). Administrative borders thus play an important role in the formation of inner peripheries (Burda 2016).

Our analysis of the territorial relationships that actors are in would be incomplete if we were to ignore the differences between horizontal and vertical interactions within the frame of social networks. Horizontal networks of actors denote first of all a relationship of reciprocity. There are no significant power disparities surrounding their formation, and this makes cooperation between individuals easier. By contrast, vertical networks rest on a slightly weaker level of cooperation but cut through all the hierarchical levels of a society (Putnam, Leonardi, Nanetti 1993). Horizontal networks of actors can to some extent be equated with the bridging and bonding types of social capital, wherein the bonding form of social capital is not as beneficial to the development of local communities as the bridging form is (Pileček, Jančák 2010). Vertical networks, which can to some extent be equated with the bonding form of social capital (Woolcock 2001), can be employed to obtain key information or, for example, the material resources that municipalities essentially need (Jančák 2001). It is therefore desirable for actors to be involved in horizontally formed communities of local actors, which are rendered more efficient through relations of trust (Raco 1998), and in activities organised on higher hierarchical levels of society.

The main aim of this paper is to understand the nature of socio-economic differences between municipalities in the region of the inner periphery. Hence, the paper firstly discusses the issue of 'soft' development factors, then presents in detail the neglected concept of institutional thickness, which is used for a partial evaluation of interactions and within which the conclusions are formulated and discussed.

A careful analysis of our interviews with mayors, who are key actors in local development, allowed us to find answers to research questions that we grouped into three sub-goals. The first partial goal is (1) to explain what internal conditions are conducive to the formation of these ties of cooperation. So, it is necessary to first classify actors (mayors) according to their possibilities to influence local events, identify their cooperation with each other within the region (or the barriers to this cooperation e.g. administrative boundaries) and ask whether they form networks, not just of formal contacts but also of informal ones, which are important for local development. An analysis of the interviews we conducted with mayors can provide some idea of the degree of institutional thickness in the studied region. A key component of the concept of institutional thickness is what power structures are involved in the ties of cooperation that this article is focusing on (2). Thus, is it possible within the region studied here to find municipalities that cooperate on a partnership basis (i.e. as equal partners), or, conversely, within the frame of differentiation on the local level do we see rather cooperation occurring between 
a clearly identified core and its periphery? Are there natural leaders in the region? The third and final partial goal (3) entails an assessment of the direction of the interactions. The following questions will be addressed. Are the interactions within the studied region primarily horizontal or are they vertical? And are the power structures in any way connected to the prevailing direction of interactions? Last but not least, another partial goal is to contribute to the theoretical discussion on the concept of institutional thickness.

\section{The 'soft' factors of research on the development of inner peripheries}

Peripheral areas have traditionally been defined by their unchanging characteristics over time. However, according to Chromý (2003), a very important role in this definition is played by a place's relative position, as the core-periphery continuum is closely connected to the urban-rural continuum (Perlín, Kučerová, Kučera 2010). Given the interconnectedness of the system it is impossible to study a periphery in isolation and it must always be examined in relation to its corresponding core in the core-periphery relationship (Havlíček, Chromý 2001; Jančák et al. 2006, 2008; Pileček 2013). It is also always necessary to discuss the scale on which we are defining and studying a periphery. What on the global or national level is a peripheral area may on the local level be a heterogeneous nodal region. Pileček (2013) also warns against creating a polarity out of the core-periphery concept, as there is some degree of peripherality to every area or region. Given the large number of indicators applied in studies of peripheral areas, the different methodologies they use, and their varied complexity, there are many and varied conceptualisations of research on peripheries, all of which are marked by some degree of subjectivity (Pileček, Jančák 2011).

According to Blažek (2012), institutional approaches to the study of regional development take a region's competitiveness as the chief desirable aspect of development. In research on competitiveness, 'soft (hard to quantify) factors' have gradually gained primacy, and this is due, among other things, to development coming to be ever more widely understood not solely in economic terms but also in a sense that considers the socio-cultural aspects of development. According to Blažek, the lower level of spatial (geographic) scale, the greater the effect and explanatory power of these (soft) factors, which means that their use in research on the local level is fully justified. It is thus on the local level that the role of the actors in local development is differentiated most (especially those actors found with greatest density in the studied region - namely, mayors).

Human and social capital can also be counted among 'soft factors'. Yet, the nature of social capital and its significance for local development are questions that have yet to be resolved. In Czechia the regional distribution and developmental 
potential of social capital have been studied by sociologists (Stachová, Bernard, Čermák 2009; Majerová, Kostelecký, Sýkora et al. 2011; Bernard 2011) and social geographers (Sýkora, Matoušek 2009; Jančák et al. 2008, 2010; Pileček, Jančák 2011; Pileček, Chromý, Jančák 2013; Marada et al. 2019). However, the most attention has been devoted to micro-regional research into the complex endogenous developmental potential of peripheral areas (Chromý, Skála 2010). In a methodological perspective, most of this research has come in the form of qualitative and primarily descriptive surveys (Jančák 2001; Stockmann 2005; Vajdová 2008; Abramuszkinová Pavlíková, Kučerová, Šmídová 2008). Adding to this, Hampl, Dostál, Drbohlav (2007) have found that the relative significance of social and human capital is directly proportional to the developmental potential of the observed locality. And the same proportional relationship applies with respect to the significance of all endogenous factors (other forms of capital - e.g. cultural capital - regional identity, etc.).

Sotarauta (2005) has focused his research on another 'soft' factor, namely leadership, and he has written about the need to mobilise activity and then to sustain that mobilisation. As any problem grows more complex and thus the chances of actors reaching an agreement decreases, the importance of leadership grows. A leader can, with the right strategy, bring about successful outcomes. Sotarauta also places importance on the development of key attributes in leaders in accordance with the competences that they have been both officially and unofficially assigned. On a more general level, Cannarella and Piccioni (2008) highlight the importance of local actors' involvement, and they classify networks as formal (formed on the basis of official agreements and with clearly defined roles and responsibilities) and - for the purpose of development the more important - informal (based on mutual understanding with no concern for any formal structure to them). Depending on the degree of dominance in the network, the same authors then distinguish between networks with a vertical, hierarchical order (where there is one dominant actor - or several dominant actors - responsible for the reproduction of relationships) and a horizontal order (none of the actors is superior of any of the others). Cannarella and Piccioni (2008) regard the existence of a stable territorial network of local actors as an essential precondition if a positive cooperative environment is to emerge out of ties that originally were primarily competitive. If the actors are not integrated into and part of a network, their actions are governed by improvisation and occur in isolation, and there are clearly discernible limits of their individual initiatives. Beugelsdijk and Van Schaik (2005), in their paper, also set horizontal cooperation above hierarchical arrangements marked by power differences. However, hierarchical arrangements may be effective and fruitfull in cases where the actors accept their superior and subordinate roles and are in pursuit of a common goal. The denser these networks are, and in which there is then also an added level of trust, the more the level of insecurity 
in them diminishes, and the more opportunities that open up for mutual learning and for sharing information (Fromhold-Eisebith 2004). Putnam, Leonardi, Nanetti (1993) have also written about societies being more effective when they have complex horizontal networks of social relations. In terms of methodology, Beugelsdijk and Van Schaik (2005) favour the use of open or semi-structured interviews and a subjective (individual) approach to study of 'soft' factors.

\section{Institutional thickness as a framework for research on the 'soft' factors of local development}

As indicated above, the results of the research are interpreted in the light of a concept that has remained almost unused in Czech research, which is the concept of institutional thickness put forth by Amin and Thrift (1994). The sole introduction to the concept in Czech scholarly literature to date is in Blažek and Uhlír (2011), and it was applied in a study by Hlaváček (2010).

Amin and Thrift (1994) were interested in the basic question of whether it is possible in the modern-day globalised world for different localities to be competitive or to at least be distinct from others in terms of their focus or some specialisation based on the way they organise their administration and the institutions they create. Amin and Thrift defined institutional thickness on the basis of four noneconomic factors. The first is (1) the presence of institutions (organisations - e.g. municipal authorities) in a region, along with (2) strong interactive ties between representatives of these institutions (i.e. mayors; this includes standard formal and informal contacts, the exchange of information, and the formation of norms and habits). The third unquantifiable factor is (3) a mutual awareness among all actors involved, wherein they all both contribute to development but are often also dependent on the community as a whole. The fourth factor is that of (4) power structures, which should be set up in a region in such a way as to minimise sectarianism and support organisation. With respect to the third factor especially development can be made to occur more quickly and effectively by 'relations of trust', as they have been discussed by Raco (1998, p. 978).

Amin and Thrift (1994) did not view the link between institutional thickness and regional development as a causal one, but rather as one that depends on many other variables and opportunities. Despite the relatively robust list of critical comments that have been directed at this concept (e.g. Henry and Pinch 2001; Rodríguez-Pose 2013; Zukauskaite, Trippl, Plechero 2017), there has yet to emerge a paper refuting the basic tenets of the concept of institutional thickness. In almost every case so far, conclusions have been formulated on the basis of case studies (e.g. Hudson 1994; Wood, Valler 2004). Despite its shortcomings (e.g. no clear specification of the critical size of the region, and the concept's inadequate 
distinction of scale levels), the concept of institutional thickness can serve as a solid framework (especially a theoretical one) for contemporary research. And despite its undeniable potential, the concept of institutional thickness is discussed very little today, not just in Czech scholarship but in research more generally.

\section{The research design and data}

The research was conducted on the territory of two self-government regions (kraj), which was then further delineated according to lower-level units of state administration and local self-government situated within the cross-border region between Central Bohemia and Eastern Bohemia, an economically underdeveloped area that is almost exactly consistent with the definition of inner peripheries provided by Musil (1988) and Musil and Müller (2008). Unlike the vast majority of outer (border) peripheries, which were impacted by the post-World War II expulsion of the German population and subsequent resettlement with new inhabitants (Kučera, Chromý 2012; Kučera, Kučerová 2012; Šerý 2014; Šerý, Šimáček 2013), this is an area that has enjoyed continuity in its development. Here, as across all of Czechia, it is possible to feel the effects of the political 'central-place' system of residential settlements set up in the state-socialist period. After it collapsed in the 1990s, numerous independent municipalities (with small populations) emerged, and they voluntarily forged associational ties with each other and established various micro-regional groups that play an important role in facilitating informal communication between mayors. Since 2004 (and Czechia's accession to the EU) many municipalities have also been part of LAG (Havlíček et al. 2008; Semian, Chromý, Kučera 2016).

According to the 'rural area' typology developed by Perlín, Kučerová and Kučera (2010), the region selected for study can be described as an economically weak, non-developing rural area with a high level of social control. For a more detailed picture, the analysis divided the region up into the administrative districts (AD) of the five municipalities in the region that are 'municipalities with the an authorised municipal office' (hereinafter AMO), namely Městec Králové, Hořice, Nový Bydžov, Kopidlno, and Jičín. The northern part of the Jičín AMO overlaps with the Protected Landscape Area of Bohemian Paradise (CHKO Český ráj), and because of the distinct nature of this area and its better opportunities for promoting tourism (Chromý, Semian, Kučera 2014; Kučera, Kučerová Kuldová, Chromý 2008), it was eliminated from the research. The research also excluded the municipalities that are the actual seat of the 'authorised municipal office' (of which there are 393 in the Czechia, 5 of them in the studied region), in part because of the distinct position they occupy in the hierarchy of settlements and territorial administration, 
and also because it was possible to observe that in many cases other municipalities' relations tended (partly due to the historical influence of the political 'centralplace system' of settlement) to be orientated in the direction of these AMO's, so their significance was to a sufficient degree manifested indirectly.

The studied region thus encompassed a total of 113 municipalities. In 38 of them semi-structured interviews were conducted with the mayors from municipalities which do not have extended state-administrative powers. That covers more than one-third of the studied region. The 17 introductory interviews were conducted in November 2016 (in each case after having received a written response from the mayors to a mass request for interviews that had been sent out), and owing to the small number of interviews conducted in the first round of interviewing, a second round of interviews was carried out in January 2017 (conducted by telephone with randomly selected mayors in order to obtain at least a $30 \%$ sample of respondents on the territory of each AMO AD). One pleasant surprise was the low rate of refusals to the request for an interview, with only two mayors excusing themselves for the reason of a lack of time. This significantly reinforced the validity of the research results.

In order to fulfil the research goals outlined above, it was necessary to obtain a sample of respondents in the studied region that would be representative in terms of the municipalities' spatial distribution and population size (see Table 1). First, Moran's I was used to assess the spatial concentration of the agreed interviews and rule out spatial autocorrelation (Spurná 2008). Based on the results of this measure, it was possible at a $99 \%$ confidence level to reject the null hypothesis that the spatial distribution of the interviews carried out was random and accept the alternative hypothesis that the interviews carried out were evenly distributed across the studied region. An even pattern of spatial distribution is much better for the validity of the results because it captures aspects of institutional thickness across the entire studied region. In order to confirm there was no spatial clustering of the municipalities in which no interviews were carried out, local G statistics were calculated (Spurná 2008). With a 95\% confidence level, this step uncovered just three places that had a higher frequency of interviews conducted, and this was largely due to the location of these municipalities along the border of the studied region and to the shape and large area of the cadastral territories of these municipalities. However, the higher frequency of interviews carried out did not pose a complication for interpreting the results - unlike, for example, the existence of a statistically significant concentration of municipalities in which no interviews were conducted would have. However, if the higher rate of interviews had been caused, for example, by the absolute frequency of relations, it would have been necessary to consider modifying the absolute values in these identified places, or at least to more sensitively interpret the respondents' statements. Representativeness was also required with respect to the population size of the 
Table 1 - Individual interview respondents (mayors) and basic information about their municipalities

\begin{tabular}{|c|c|c|c|c|c|c|}
\hline Municipality & $\begin{array}{l}\text { Authorised } \\
\text { municipal } \\
\text { office }\end{array}$ & $\begin{array}{l}\text { Municipal } \\
\text { population } \\
\text { size (2011) }\end{array}$ & $\begin{array}{l}\text { Age } \\
\text { of the } \\
\text { mayor } \\
(2017)\end{array}$ & $\begin{array}{l}\text { Sex } \\
\text { of the } \\
\text { mayor }\end{array}$ & $\begin{array}{c}\text { Full-time } \\
\text { (FT) / } \\
\text { Part-time } \\
\text { (PT) } \\
\text { mayor }\end{array}$ & $\begin{array}{l}\text { Number of } \\
\text { terms in office as } \\
\text { mayor (current } \\
\text { term included) }\end{array}$ \\
\hline Boháňka & \multirow[t]{9}{*}{ Hořice } & 229 & 42 & male & PT & 2 \\
\hline Červená Třemešná & & 151 & 49 & male & PT & 1 \\
\hline Dobrá Voda & & 572 & 55 & female & FT & 4 \\
\hline Jeřice & & 388 & 55 & male & PT & 1 \\
\hline Miletín & & 895 & 44 & male & FT & 3 \\
\hline Milovice u Hořic & & 309 & 69 & male & PT & 2 \\
\hline Ostroměř & & 1,381 & 68 & male & FT & 1 \\
\hline Sukorady & & 212 & 54 & male & PT & 3 \\
\hline Vřesník & & 87 & 51 & male & PT & 3 \\
\hline Češov & \multirow[t]{10}{*}{ Jičín } & 209 & 40 & male & PT & 1 \\
\hline Konecchlumí & & 379 & 35 & male & PT & 1 \\
\hline Kostelec & & 38 & 42 & male & PT & 4 \\
\hline Kovač & & 128 & 44 & male & PT & 2 \\
\hline Ohaveč & & 83 & 41 & female & PT & 1 \\
\hline Slatiny & & 537 & 46 & male & PT & 1 \\
\hline Střevač & & 283 & 54 & female & FT & 1 \\
\hline Tuř & & 170 & 43 & male & PT & 3 \\
\hline Úlibice & & 284 & 53 & male & PT & 1 \\
\hline Vysoké Veselí & & 876 & 59 & male & FT & 6 \\
\hline Cholenice & \multirow[t]{5}{*}{ Kopidlno } & 230 & 44 & female & PT & 2 \\
\hline Rokytňany & & 114 & 66 & female & PT & 1 \\
\hline Staré Hrady & & 190 & 51 & male & PT & 2 \\
\hline Údrnice & & 281 & 44 & male & PT & 2 \\
\hline Zelenecká Lhota & & 159 & 47 & female & PT & 4 \\
\hline Dobšice nad Cidlinou & \multirow{6}{*}{$\begin{array}{l}\text { Městec } \\
\text { Králové }\end{array}$} & 236 & 48 & male & PT & 2 \\
\hline Dymokury & & 873 & 56 & female & FT & 1 \\
\hline Hradčany & & 253 & 43 & male & PT & 1 \\
\hline Kněžice & & 494 & 54 & male & FT & 4 \\
\hline Podmoky & & 201 & 68 & male & PT & 1 \\
\hline Sloveč & & 515 & 52 & male & PT & 1 \\
\hline Barchov & \multirow{8}{*}{$\begin{array}{l}\text { Nový } \\
\text { Bydžov }\end{array}$} & 312 & 61 & male & PT & 7 \\
\hline Kobylice & & 271 & 42 & male & PT & 1 \\
\hline Lužec nad Cidlinou & & 489 & 31 & male & PT & 2 \\
\hline Měník & & 608 & 53 & female & PT & 1 \\
\hline Myštěves & & 181 & 63 & male & PT & 5 \\
\hline Nepolisy & & 962 & 32 & male & FT & 2 \\
\hline Skřivany & & 1,061 & 37 & female & FT & 1 \\
\hline Smidary & & 1,555 & 58 & female & FT & 3 \\
\hline
\end{tabular}

Source: Czech Population and Housing Census 2011, Volby.cz 
Table 2 - The questions posed in the interviews with respondents

Have you formed any contacts through your work in public office? Do you make use of them? Do you maintain these contacts in the long term? If you do, can you mention one example of you making repeated use of a contact?

Are you currently cooperating with anyone outside your municipality? When and how did you establish this contact (or someone else established it with you)? With whom? What is the nature of these contacts?

How much time do you find left to engage in cooperation with actors in other municipalities for the purpose of resolving urgent internal affairs in the municipality?

Whom do you put trust in/rely on for work purpose? Do you know of anyone who puts their trust in/relies on you? Why and on what matters? How much?

Do you actively communicate with higher administrative units? Who initiates the communication? How frequently does it occur? Are these balanced or one-sided discussions?

Does anyone in your vicinity naturally have a greater say in matters? Who? Why?

Do members of the municipal council support your views? Do they have confidence in your abilities?

Source: Author's field survey (November 2016 - January 2017)

municipality the respondent represented, and it was measured and confirmed using a paired Wilcoxon test.

In conformity with the aim of this study, the structure of the interview was formulated as follows (see Table 2). The interview structure outlined above chiefly served as just the basic frame for the more in-depth interviews which often (in exactly one-half of the cases) continued for more than an hour. The shortest interview lasted approximately one-quarter of an hour. The interviews were audio-recorded in full, except for one, which was recorded in writing. Based on the interviews a table was created, with 38 columns and 121 rows that contains more than 4,500 items of information. Each column presents the data obtained from the mayor of a municipality and the rows provide information on the individual characteristics that were surveyed in the interview. The data were drawn directly from this table to create specific outcomes. The standardised responses given in the table are accompanied by several dozen additional uncategorised comments that respondents made and that are cited below in direct quotes or are paraphrased. All evaluations (of the subjects' activities) and the activity of mayors on supra-municipal levels were recoded on a numerical scale running from 1 (the best/the highest) to 5 (the worst/the lowest). The table and the complete database produced by this research are resources whose information value is greater than the goals of this paper. The next section presents individual data in the form in which they were analysed. First, it looks at the division of actors (mayors) into six basic groups. It then focuses on the cooperation between actors in the studied region and identifies local leaders. Finally, it offers an analysis of the institutional thickness of the studied region. 


\section{The different roles, possibilities, and individual abilities of mayors across municipalities}

In the municipalities with the smallest populations, mayors are not free to perform the office of mayor full time, and they usually have a full-time job as well as being mayor (see Fig. 1). Given the 'bureaucratic workload' and 'frequent paperwork' some of them explicitly referred to, these mayors have almost no time for activities on the supra-municipal level. Part-time mayors who also run a business or have flexible or reduced working hours are only slightly better off in this respect. However, even they do not go about initiating more intermunicipal ties than are absolutely necessary (i.e. they tend to maintain formal ties). In one municipality, the council went so far as to conclude that 'only a senior citizen would be able to be mayor, because only they have enough time and they don't cost anything'. But even having a senior citizen as a part-time mayor did not prove to be the ideal choice in order to get the municipality involved in activities on the supra-municipal or inter-municipal levels. In some places, these part-time mayors know nothing, for example, about the real purpose of LAG and other entities working to improve rural development.

Among municipalities with larger populations (generally those with more than 500 inhabitants) the percentage of mayors who perform their function full time is larger. The more passive of the full-time mayors often mentioned the opportunities they'd had to take part in meetings on the supra-municipal level, but on these occasions they had usually only made a small number of formal or informal contacts

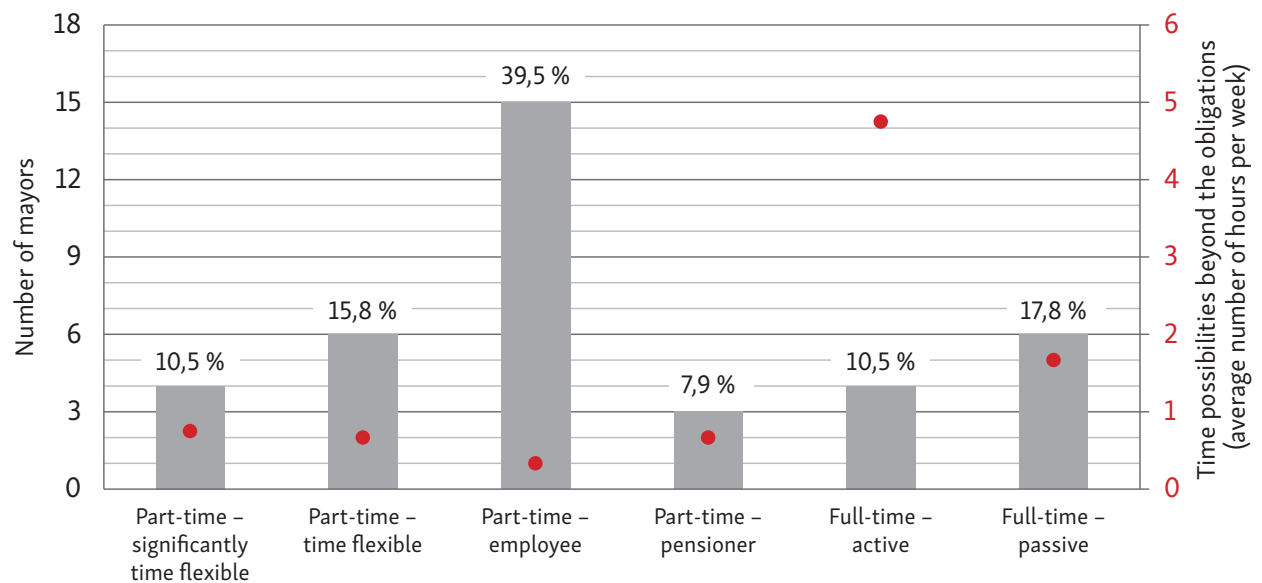

Fig. 1 - Differentiation of mayors in studied region according to their activity, employment and the average number of hours per week they may devote to real development $(n=38)$. Source: Author's field survey (November 2016 - January 2017). 
that they made rare use of for the purpose of the municipality's operations. Active full-time mayors, however, participate in local projects not only in their function as mayor, but often also do so in a managerial role in a LAG or in some other local or regional group (some voluntary associations of municipalities - e.g. Rozhraní (AMO Kopidlno) - have even become the seat of a newly emerged LAG). Many mayors have in the past managed to get their municipality, even if it had just a relatively small population, made the seat of a LAG. Mayors in this category are highly productive at work and they account for approximately one-tenth of the mayors in the studied region.

\section{The variety and conditions of cooperation between actors}

How mayors operate with their municipality links fluidly to how they act within the framework of the local community. Therefore, one of the sub-goals of the study was to identify cooperation between mayors and explain the conditions on which the formation of these ties of cooperation is based in the studied region. As well as the specific ties of cooperation that the mayors themselves mentioned, the map created as the outcome of the analysis (Fig. 2) also captures the difference between ties of cooperation on the individual level and broader cooperation between whole municipalities (cooperation that includes other members of the municipal councils or potentially even other actors, which was learned about indirectly from the interviews with the mayors), and it captures the differences between formal and informal types of cooperation and the vertical or horizontal direction of interactions between actors in local development. A significant finding is the confirmation of substantial spatial heterogeneity, the factors behind which are the above-noted internal differentiation of the sample of mayors and historical development (where to date the political 'central-place system' of settlement still exists). Except for two mayors who were very passive in establishing contacts, the other mayors differed from each other according to whether their ties of cooperation operated more on a personal basis or whether additional municipal councillors or other actors were also involved in intermunicipal cooperation. An interesting situation was observed within the AD of the Kopidlno MEP, which slightly extends into the territory of the AD of the Jičín MEP. According to the respondents, most of the municipal cooperation in the Kopidlno AD occurred on the individual, inter-personal level. To understand why this form of cooperation advanced more in this $\mathrm{AD}$ it is enough to know about the existence of the association of municipalities Rozhraní, a voluntary and now defunct association, within the frame of which, the mayors stated, there were frequent informal interactions, but these only contributed to a small degree to the development of more intensive (i.e. broadly based) cooperation. 


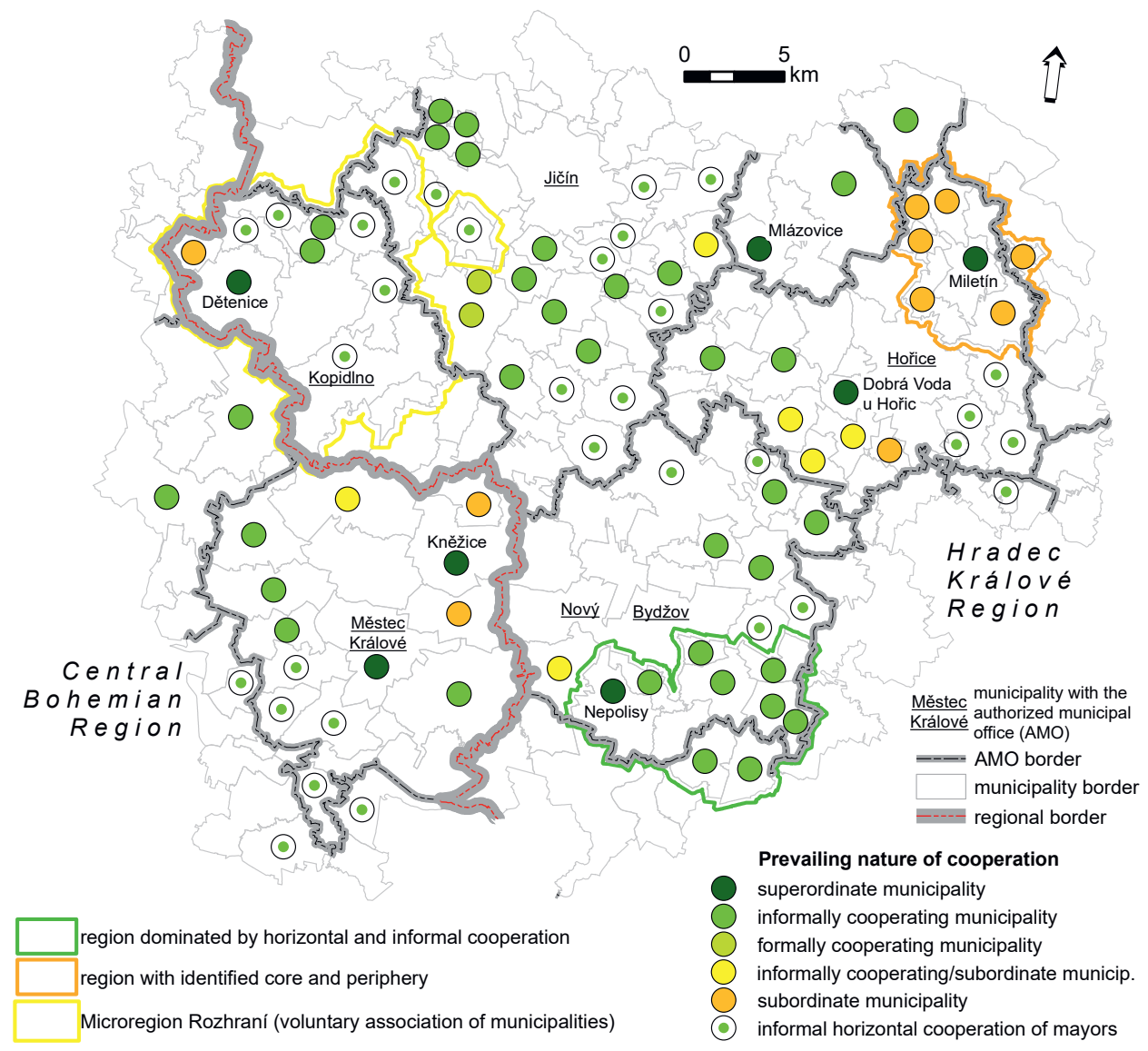

Fig. 2 - Cooperation of the municipalities in the studied region according to its prevailing character. Constructed on the basis of the formality of the relationships, the direction of the interactions and power relations. No cooperation was identified where there is no any diagram. Source: Author's field survey (November 2016 - January 2017).

An important role in regional development is also played by how formal or informal the ties or relations are. Formal relations (e.g. the coordinating of activities within the catchment area of a primary school) often involve vertical interactions, while informal relations (e.g. cultural events organised by several municipalities and with the involvement of municipal councillors that are open to the public) in many cases are horizontally structured and based on partnerships. A prime example of horizontal cooperation between partners is represented by a group of municipalities in the south and the east of the AD of the Nový Bydžov MEP that also cooperate with municipalities in the Chlumec AD (see Figure 2; the areas marked in green dominated by horizontal and informal cooperation). It is this 
ability of actors (mayors) to together form an informal higher-level cooperative alliance that helps to sustain a high level of activity.

The opposite form of relations between municipalities, i.e. a vertical structure of relations of a more formal nature, can be observed in the southeast of the Hořice AD. Clear evidence that ties formed through the political 'central-place system' of municipalities during the state-socialist period have survived into the present day is the superordinate position that Miletín occupies in relations between the mayors, and this was confirmed in interviews with the mayors of surrounding municipalities. On the lowest scale level, this could be described as a core-periphery relationship. A similar dichotomy but with a far smaller periphery was identified around Dětenice, a municipality that has ties of cooperation to several municipalities within the AD of Kopidlno MEP but in them occupies a superordinate position, and its importance for local development overshadows even that of the Kopidlno MEP itself. A weaker polarity can also be observed in the periphery of Dobrá Voda u Hořic municipality, but unlike the situation around Miletín, the central position Dobrá Voda u Hořic municipality occupies is accompanied by the existence of informal ties of cooperation between municipalities in its periphery. The last area where predominantly vertical interactions can be observed is in a little region with two cores that is located in the northeast part of the Městec Králové $\mathrm{AD}$ and where the Městec Králové municipality and the Kněžice municipality are both in a superordinate position. The importance of Kněžice is moreover heightened by the fact that it is the seat of a LAG. The reason that relations within the Městec Králové $\mathrm{AD}$ have formed along vertical lines, in the opinion of more than one mayor in this $\mathrm{AD}$, is because this $\mathrm{AD}$ is also where the border of the self-government region is located and, according to three local mayors, there are almost no ties that run across this border. But it is also because there are strong mayors in office in both Městec Králové municipality and Kněžice municipality. They are both located in the peripheral part of the Central Bohemia self-government Region, where there are limited opportunities for cooperation with municipalities or actors around them, that is, on the other side of the region's border, because they belong to different self-government regions.

The municipality of Dymokury in the northwest part of the Městec Králové AD is geographically in a better position than the municipalities of Městec Králové and Kněžice (it does not lie in close proximity to the border of a higher-level administrative unit). Given the possibilities it thus has for cooperating with the neighbouring municipalities around it, the majority of these municipalities have formed horizontal ties with each other. It is important to add, however, that the strong ties of cooperation that exist between municipalities Dymokury and Křinec (population size approx. 1,300) and between municipalities Dymokury and Rožd'alovice (population size approx. 1,600), though horizontal, depend more on the more largely populated municipalities which have full-time mayors who 
are able to devote more time to their function. Like in the area to the northeast of the Městec Králové $\mathrm{AD}$, in the Kopidlno AD on the very edge of the Hradec Králové self-government Region, there are again voices that point to the difficulty of forming contacts across the border of a self-government region.(more about it e.g. Burda 2016).

Surprisingly, even the MEP do not sufficiently participate in local cooperation (these are higher-level administrative units with more staff). This is due to their official status as the seat of a higher-level unit of administration, and external communication thus proceeds through special officials rather than through the mayor and council. Informal cooperation is assumed to exist on a higher level in the administrative hierarchy (between the AMO and MEP themselves), which could be ascertained in follow-up research. In the words of the mayor of the closest periphery of Jičín municipality, 'Jičín focuses primarily on the administration of its territory, the counsel we receive from it is the most important for us, but we receive it at the office of the municipal authorities or indirectly, not from its council or its mayor'. From the relationship thus implied that exists with the largest town within an $\mathrm{AD}$ it is possible to infer that most mayors regard assistance from larger towns as a very vertical relationship (and also, e.g., as 'news from the centre'). By contrast, Kopidlno MEP and Městec Králové MEP are both engaged in intermunicipal cooperation. Kopidlno MEP is a regular member of the former association of municipalities Rozhraní, whose members collectively joined a LAG. Only the mayor of Kopidlno is in contact with the mayors of the surrounding municipalities (in that $\mathrm{AD}$ ). In the words of one of the mayors of the surrounding municipalities, 'there is no need to engage in formal cooperation with Kopidlno municipality, only our building authority is there, where we sometimes have to go to sort out formalities, and we only know the mayor from LAG gatherings'. In the Městec Králové municipality, by contrast, there is a strong figure in the position of mayor, and the contact that the mayors from surrounding municipalities have with this MEP goes beyond 'sorting out formalities' with the building authority (see Fig. 3).

A key finding from this research is the absence of any form of cooperation in municipalities in the Hradec Králové self-government Region on the border of the Central Bohemia self-government Region and located to the northwest of Nový Bydžov and southeast of Kopidlno. Based on the findings shown in Figures 2 and 3 , this area can be regarded in the extreme case as institutionally excluded and socially marginalised (Musil, Müller 2008). According to the concept of institutional thickness, this kind of area is characterised by the complete absence of informal institutions, non-participation in power structures, and a lack of any sense of an attachment to other actors and organisations. In this kind of case, the municipal authorities are an organisation that has minimal formal ties (often even those required by legislation). 


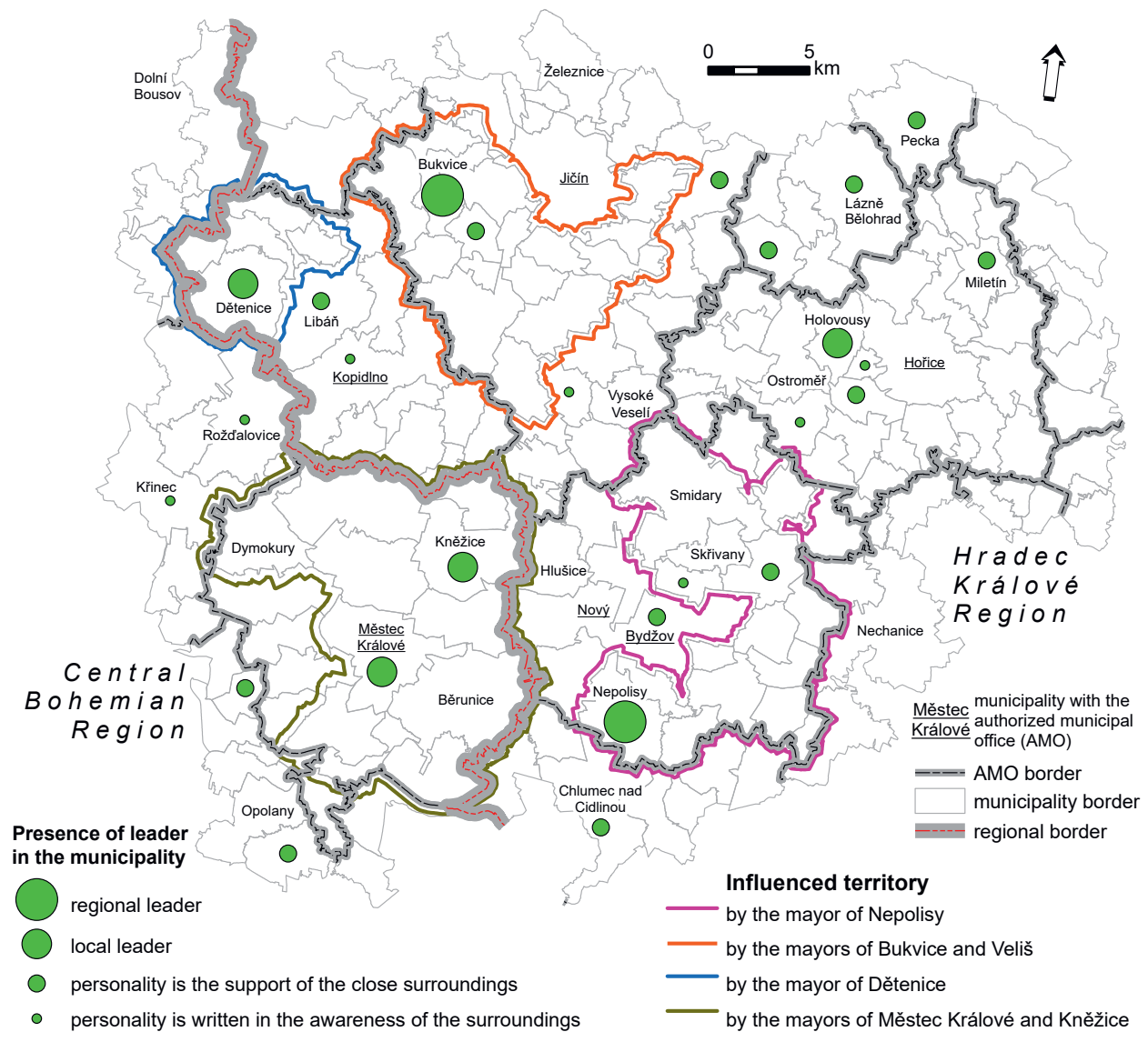

Fig. 3 - Leaders of the studied region and surrounding area influenced by these leaders. The size of the diagram represents the absolute frequency of the references (1, 2, 4 and 7). Source: Author's field survey (November 2016 - January 2017).

We can see from Figure 3 that the most important figures within the entire studied region are the mayors of Bukvice and Nepolisy. Both these mayors have an influence on a wider area not only through their position as mayor of their municipality, but also through the managerial roles they play within the LAG. These two most important figures in the studied region are both representatives of well-integrated areas with a good level of informal cooperation. We also find figures that are important for the local community in the position of the mayor of Dětenice and in the aforementioned mayors of Městec Králové and Kněžice. In these cases, however, they are not representatives of areas with a good level of (internal) cooperation where a basic goal is to offer a sophisticated approach to improving an atmosphere that is already quite good; rather, they are individuals 
who are providing support to the area around them on relatively elementary (and oftentimes internal municipal) issues.

In no case does the impact of any of these key figures mentioned above extend into the problem area along the regional border that stretches from the municipalities northwest of Nový Bydžov to the municipalities southeast of Kopidlno. The local figure identified in Holovousy municipality in the Hořice AD is no longer in office, her influence was moreover considerably fragmented. Therefore, in this case (in Figure 3) there is no undivided boundary that marks the reach of her influence. The important role she once occupied is slowly but steadily being assumed by the mayor of Dobrá Voda u Hořic.

The interviews also revealed that a figure identified as a leader in an area is trusted more by the other mayors, which has the expected consequence of increasing the effectiveness of the ties between them. A higher level of trust is also enjoyed by the representatives of areas with horizontal ties of cooperation.

With respect to the relationship of municipalities to higher-order units of state administration, it is worth mentioning one anomaly that was frequently mentioned by the mayors. The nature of the relations that the municipalities of the Nový Bydžov AD have with the regional administrative bodies in the Hradec Králové self-government Region is extremely negative, even though the $\mathrm{AD}$ of the Nový Bydžov MEP is the area in the studied region closest to the (selfgovernment) regional capital of the Hradec Králové self-government Region. The negative relations the municipalities of the $\mathrm{AD}$ have with regional administrative bodies are probably the result of the position of independence that most of the interviewed mayors have in a powerful local initiative that is led and supported by the mayor of Nepolisy and the entire LAG named Společná Cidlina. This example demonstrates that a LAG with good leadership that is intelligible and beneficial to all its members is a more effective developmental tool than are relations with regional bodies (based on several interviews in this area it could even be postulated that when there is a well-functioning LAG in place, municipalities 'rebel against regional bodies that operate in an overly top down and formal manner' and limit their contact with them to just an officially necessary minimum). The activity of LAGs in the studied region (and especially how that activity is perceived) varies considerably. There are relatively well-functioning LAGs operating in the Hořice $\mathrm{AD}$ and the aforementioned AD's of Nový Bydžov and Městec Králové; by contrast, the activity of the LAG in the Jičín AD is viewed negatively. Other organisations aiding in the development of rural areas (the mayors most often referred to the Association of Local Municipalities, the Association for Rural Regeneration, and the Federation of Towns and Municipalities) 'have almost no regional impact' and often run up against the constraints on their time that mayors must contend with (in the words of one mayor it is an 'extra activity with no marked payback'). 


\section{A summary of the key findings}

Based on the research that was conducted in the inner periphery in the crossborder region between Central Bohemia and Eastern Bohemia it is possible to confirm the formulated assumption that this region is a periphery, not only in terms of how socio-economically advanced it is (Musil, Müller 2008; Novák Netrdová 2011) but also with respect to the 'soft factors' that were analysed (Blažek 2012). The research also confirmed that administrative borders play a role in the formation of ties and relations within the region (Burda 2016), which is something that is considered a characteristic feature of inner peripheries. 'Soft' qualitative factors also have a significant effect. Developmental differences between municipalities that are set in otherwise almost identical 'external frames' can be the product of differences in the quality of their human resources and the latter's ability to comprehensively mobilise a municipality's endogenous potential (Chromý et al. 2011). One 'internal condition' that varies, for example, is the role of mayors in the municipalities, where there are immense differences between full-time and part-time mayors in terms of the amount of time they have to devote to their office and the pool of contacts they are able to form. Another such condition is the degree of historical inertia there is to existing municipal ties. The research also confirmed that regional development also depends strongly on the presence of key and capable actors who have numerous formal and informal contacts, both horizontal and vertical ones. Whether a particular region would benefit more from horizontal or from vertical ties is largely determined by the historical development of settlement in that region.

On the issue of institutional thickness, the following conclusions can be formulated. Given how highly scattered municipalities are across Czechia as a whole (1) municipal mayors can be deemed key actors in local development and, indirectly, municipal offices are thus key institutions. The frequency with which municipal offices engage in cooperation with other municipal offices, businesses, the non-profit sector, and active citizens is found to be an important resource for endogenous development. These contacts are very diverse in the area. Whether the mayors use primarily formal contacts or make extensive use of informal ties depends largely on their role in the local self-government (full-time mayors are in a better position to do so than part-time mayors).

(2) Based on the ties of cooperation identified among mayors and the prevalence of horizontal or vertical interactions the research confirmed that ties between municipalities and especially between key actors in local development that were formed in the period before the collapse of the communist regime in 1989, when a political 'central-place system' of municipalities existed, continue to exist to the present day. A prime example of this is the historical inertia that lies behind the vertically superordinate position occupied by the municipality of Miletín 
in the northeast of the Hořice $\mathrm{AD}$, which was confirmed by three respondents. On the lowest scale level (the municipal level), we can define this area (specifically outlined in Figure 2) as a functional region with a very distinct core-periphery relationship. Multiple municipalities in a vertically superordinate position were also identified (Dětenice, Dobrá Voda u Hořic, and Kněžice and Městec Králové together), and only in the northeast of the Hořice $\mathrm{AD}$ in the periphery of Miletín did there not in addition exist also horizontal contacts between the municipalities. No sign of local differentiation in the form of an identifiable core and its periphery can be identified in the south and in the east of Nový Bydžov.

(3) For areas where mayors regularly cooperate with each other and where interactions are predominantly horizontal and contacts informal, what is of crucial importance, in the view of the respondents, is that there exists a well-functioning LAG in which naturally stronger individuals with knowledge of the specifics of local events are active. There is an area in the studied region (in the south of the Nový Bydžov AD, see Fig. 2 and 3) that works exclusively with numerous informal contacts. It might mistakenly seem that this area is flourishing because of its close proximity to a regional capital, but the work of the regional administrative bodies in the Nový Bydžov AD was poorly evaluated (by mayors in the $\mathrm{AD}$ ) for coming across as too 'formal and overly top down'. Across most of the territory of the AD of the Nový Bydžov MEP there is a well-function LAG called Společná Cidlina that grew out of several micro-regional groups that existed before it and functioned well (the Associations of Municipalities Pocidlinsko, Nový Bydžov and Cidlina). One of the two most highly regarded figures in the entire studied region, the mayor of Nepolisy, is involved in this LAG.

And finally (4) the borders of territorial administrative units are of fundamental significance in that they constrain the formation of both formal and informal relations between actors in local development. A spatial analysis of ties of cooperation between mayors and leading figures in the studied region revealed the existence of institutionally excluded and socially marginalised areas along the border between self-governments regions (Musil, Müller 2008), areas in which the mayors do not maintain any intermunicipal ties. Regional borders have the most pronounced effect on the formation of relations between municipalities. The lower the level of administrative unit within the administrative hierarchy, the weaker the significance of the border's effect, but there nevertheless remains an identifiable effect.

When using the concept of institutional thickness an explanatory framework (also thanks to this paper, its undisputed potential has been highlighted), similar and follow-up studies (not only focused on the peripheral areas but also more generally focused on rural areas) should not fail to consider also the role of mayors, who are key actors on local development, and the role of the borders of the territorial administrative unit in forming ties or ignore the significance of the given historical context. 


\section{References}

ABRAMUSZKINOVÁ PAVLÍKOVÁ, E., KUČEROVÁ, E., ŠMÍdOVÁ, M. (2008): Periferie zblízka: studie tří periferních obcí a jejich sousedů. FSV UK, Praha.

AMIN, A., THRIFT, A. (1994): Living in the Global. In: Amin, A., Thrift, N. (eds.): Globalization, institutions and regional development in Europe. Oxford University Press, Oxford, 1-22.

BERNARD, J. (2011): Endogenní rozvojové potenciály malých venkovských obcí - obtížné hledání a měření jejich vlivu. Sociologický časopis, 47, 4, 745-775.

BERNARD, J., KOSTELECKÝ, T., ILLNER, M., VOBECKÁ, J. (2011): Samospráva venkovských obcí a místní rozvoj. SLON, Praha.

BEUGELSDIJK, S., VAN SCHAIK, T. (2005): Differences in social capital between 54 Western European regions. Regional Studies, 39, 8, 1053-1064.

BLAŽEK, J. (2005): Trends to regional disparities in the Czech Republic in pre-accession period in the European context. Geographica Polonica, 78, 2, 91-106.

BLAŽEK, J. (2012): Regionální inovační systémy a globální produkční sítě: dvojí optika na zdroje konkurenceschopnosti v současném světě? Geografie, 117, 2, 209-233.

BLAŽEK, J., UHLÍŘ, D. (2011): Teorie regionálního rozvoje: nástin, kritika, implikace. Karolinum, Praha.

BURDA, T. (2016): Historické hranice a proces polarizace prostoru v Česku. Nakladatelství P3K s.r. o., Praha.

CANNARELLA, C., PICCIONI, V. (2008): Innovation diffusion and architecture and dynamics of local territorial network. Trames: A Journal of the Humanities \& Social Sciences, 12, 2, 215-237.

DOSTÁL, P., HAMPL, M. (2002): Regional development in the Czech Republic: specific and general tendencies. In: Domanski, R. (ed.): Cities and regions in enlarging European Union. Polish Academy of Sciences, Warszawa, 129-149.

FRIEDMANN, J. (1972): A general theory of polarized development. In: Hansen, N.M. (ed.): Growth centres in regional economic development. Free Press, New York, 82-107.

FROMHOLD-EISEBITH, M. (2004): Innovative milieu and social capital - complementary or redundant concepts of collaboration-based regional development? European Planning Studies, 12, 6, 747-765.

HAMPL, M. (2007): Regionální diferenciace současného socioekonomického vývoje v České republice. Sociologický časopis, 43, 5, 889-910.

HAMPL, M., BLAŽEK, J., ŽÍǏZLOVÁ, P. (2008): Faktory - mechanizmy - procesy v regionálním vývoji: aplikace konceptu kritického realizmu. Ekonomický časopis, 53, 7, 696-711.

HAMPL, M., DOSTÁL, P., DRBOHLAV, D. (2007): Social and cultural geography in the Czech Republic: under pressures of globalization and post-totalitarian transformation. Social \& Cultural Geography, 8, 3, 475-493.

HAVLÍČEK, T., CHROMÝ, P. (2001): Příspěvek k teorii polarizovaného vývoje území se zaměřením na periferní oblasti. Geografie, 106, 1, 1-11.

HAVLÍČEK, T., CHROMÝ, P., JANČÁK, V., MARADA, M. (2008): Innere und äußere Peripherie am Beispiel Tschechiens. Mitteilungen der österreichischen Geographischen Gesellschaft, 150, 299-316.

HENRY, N., PINCH, S. (2001): Spatialising knowledge: placing the knowledge community of Motor Sport Valley. Geoforum, 31, 2, 191-208.

HLAVÁČEK, P. (2010): Aktéři a mechanismy regionálního rozvoje na př́íkladu Ústeckého kraje. Dissertation. PřF UK, Praha. 
HUDSON, R. (1994): Institutional change, cultural transformation, and economic regeneration: myths and realities from Europe's old industrial areas. In: Amin, A., Thrift, N. (eds.): Globalization, institutions and regional development in Europe. Oxford University Press, Oxford, 196-216.

CHROMÝ, P. (2003): Historical-geographical and cultural-geographical research of the development in border, marginal and peripheral regions in Czechia. In: Kowalczyk, A. (ed.): Theoretical and methodological aspects of geographical space at the turn of the century. Warsaw University, Faculty of Geography and Regional Studies, Warszaw, 187-192.

CHROMÝ, P., JANČÁK, V., MARADA, M., HAVLÍČEK, T. (2011): Venkov - žitý prostor: regionální diferenciace percepce venkova představiteli venkovských obcí v Česku. Geografie, 116, $1,23-45$.

CHROMÝ, P., SEMIAN, M., KUČERA, Z. (2014): Regionální vědomí a regionální identita v Česku: př́padová studie Českého ráje. Geografie, 119, 3, 259-277.

CHROMÝ, P., SKÁLA, J. (2010): Kulturněgeografické aspekty rozvoje příhraničních periferií: analýza vybraných složek územní identity obyvatelstva Sušicka. Geografie, 115, 2, 223-246.

ILLNER, M. (1992): K sociologickým otázkám místní správy. Sociologický časopis, 28, 4, 480-492.

ILLNER, M. (1996): K otázce reprezentativnosti místních zastupitelstev. In: Hampl, M. (ed.): Geografické organizace společnosti a transformační procesy v České republice. PřF UK, Praha, 343-351.

JAKEŠOVÁ, L., VAISHAR, A. (2012): Sustainable inner peripheries? A case study of the Olešnice micro-region (Czech Republic). Moravian Geographical Reports 20, 4, 13-25.

JANČÁK, V. (2001): Příspěvek ke geografickému výzkumu periferních oblastí na mikroregionální úrovni. Geografie, 106, 1, 26-35.

JANČÁK, V., HAVLÍČEK, T., CHROMÝ, P., MARADA, M. (2006): Research on peripheral regions in Czechia: Theorethical and methodological remarks and basic results. AUC-Geographica, 48, 89-99.

JANČÁK, V., HAVLÍČEK, T., CHROMÝ, P., MARADA, M. (2008): Regional differentiation of selected conditions for the development of human and social capital in Czechia. Geografie, $113,3,269-284$.

JANČÁK, V., CHROMÝ, P., MARADA, M., HAVLÍČEK, T., VONDRÁČKOVÁ, P. (2010): Sociální kapitál jako faktor rozvoje periferních oblastí: analýza vybraných složek sociálního kapitálu v typově odlišných periferiích Česka. Geografie, 115, 2, 207-222.

KOMÁREK, M. (2017): Role měkkých faktorů v rozvoji vnitřní periferie východních Čech. Thesis. PřF UK, Praha.

KUČERA, Z., CHROMÝ, P. (2012): Depopulation, resettlement and landscape changes in the peripheries of the Czech borderland. In: Paniagua, A., Bryant, R., Kizos, T. (eds): The Political Ecology of Depopulation: Inequality, Landscape, and People. Rolde Foundation, CEDDAR, Zaragoza, 191-213.

KUČERA, K., KUČEROVÁ, S. (2012): Historical geography of persistence, destruction and creation: The case of rural landscape transformations in Czechia's resettled borderland. Historická geografie 38, 1, 165-184.

KUČERA, Z., KUČEROVÁ KULDOVÁ, S., CHROMÝ, P. (2008): Landscape heritage between areal preservation and areal development - the case of Czechia. Geographia Polonica 81, 2, 5-23.

KUHN, M. (2015): Peripheralization: Theoretical concepts explaining socio-spatial inequalities. European Planning Studies, 23, 2, 367-378. 
MAJEROVÁ, V., KOSTELECKÝ, T., SÝKORA, L. et al. (2011): Sociální kapitál a rozvoj regionu. Příklad Kraje Vysočina. Grada Publishing a. s., Praha.

MARADA, M., CHROMÝ, P., JANČÁK, V., HAVLÍČEK, T. (2006): Space polarisation and peripheral regions in Czechia. Europa XXI, 15, 29-34.

MARADA, M., CHROMÝ, P., JANČÁK, V., HAVLÍČEK, T., PILEČEK, J. (2019): Spatial differentiation of social capital: A case study of peripheral and rural microregions in Czechia. In: Leimgruber W., Chang C. (eds): Rural areas between regional needs and global challenges. Perspectives on Geographical Marginality. Springer, Cham, 31-51.

MUSIL, J. (1988): Nové pohledy na regeneraci našich měst a osídlení. Územní plánování a urbanismus, 15, 67-72.

MUSIL, J., MÜLLER, J. (2008): Vnitřní periferie v České republice jako mechanizmus sociální exkluze. Sociologický časopis, 44, 2, 321-348.

NOVÁK, J., NETRDOVÁ, P. (2011): Prostorové vzorce sociálně-ekonomické diferenciace obcí v České republice. Sociologický časopis, 47, 4, 717-744.

PERLÍN, R., HUPKOVÁ, M. (2010): Venkovy a venkované. Ministerstvo pro místní rozvoj ČR, Praha.

PERLÍN, R., KUČEROVÁ, S., KUČERA, Z. (2010): Typologie venkovského prostoru Česka. Geografie, 115, 2, 161-187.

PILEČEK, J. (2013): Sociální a lidský kapitál jako faktor rozvoje periferních oblastí Česka. Dissertation. PřF UK, Praha.

PILEČEK, J., CHROMÝ, P., JANČÁK, V. (2013): Social capital and local socio-economic development: The case of Czech peripheries. Tijdschrift voor Economische en Sociale Geografie, 104, 5, 604-620.

PILEČEK, J., JANČÁK, V. (2010): Can social capital be measured? An analysis of territorial differences among the districts of Czechia. Geografie, 115, 1, 78-95.

PILEČEK, J., JANČÁK, V. (2011): Tehoretical and methodological aspects of the identification and delimitation of peripheral areas. AUC-Geographica, 46, 1, 43-52.

POCIUTE-SEREIKIENE, G. (2019): Peripheral regions in Lithuania: the results of uneven development. Regional Studies, Regional Science, 6, 1, 70-77.

PUTNAM, R., LEONARDI, R., NANETTI, R.Y. (1993): Making democracy work. Princeton University Press, Princeton, New Jersey.

RACO, M. (1998): Assessing "institutional thickness" in the local context: a comparison Cardiff and Sheffield. Evrironment and Planning A, 30, 6, 975-996.

RODRÍGUEZ-POSE, A. (2013): Do institutions matter for regional development? Regional Studies, 47, 7, 1034-1047.

SEMIAN, M., CHROMÝ, P., KUČERA, Z. (2016): Name as a regional brand: The case of Local Action Groups in Czechia. Journal of Language and Politics, 15, 6, 768-789.

SIWEK, T. (2012): Inner divisions of the Czech Republic. Geographia Polonica 85, 1, 23-31.

SOTARAUTA, M. (2005): Shared leadership and dynamic capabilities in regional development. In: Sagan, I., Halkier, H. (ed.): Regionalism contested: institution, society and governance. Urban and Regional Planning and Development Series, Ashgate, Cornwall.

SPURNÁ, P. (2008): Prostorová autokorelace - všudypřítomný jev při analýze prostorových dat? Sociologický časopis, 44, 4, 767-787.

STACHOVÁ, J., BERNARD, J., ČERMÁK, D. (2009): Sociální kapitál v České republice a v mezinárodním srovnání. Sociologická studie. Sociologický ústav AV ČR, Praha.

STOCKMANN, J. (2005): Moravské Kopanice: identita na periferii. In: Novotná, M. (ed.): Problémy periferních oblastí. PřF UK, Praha. 
SÝKORA, L, MATOUŠEK, R. (2009): Sociální kapitál a teritorialita sociálních sítí. In: Lipský, Z., Popková, K., Poštolka, V., Šmída, J. (eds.): Geodny Liberec 2008: výroční mezinárodní konference ČGS, sborník př́spěvků. TUL, Liberec, 50-56.

ŠERÝ, M. (2014): The identification of residents with their region and the continuity of sociohistorical development. Moravian Geographical Reports 22, 3, 53-64.

ŠERÝ, M., ŠIMÁČEK, P. (2013): Vnímání hranic obyvatelstvem regionů s rozdílnou kontinuitou socio-historického vývoje jako dílčí aspekt jejich regionální identity. Geografie, 118, 4, 392-414.

VAISHAR, A. (2006): Regional periphery: what does it mean? Europa XXI, 15, 7-12.

VAJDOVÁ, Z. (2008): Aktéři místního rozvoje regionu Orlicko. Sociologická studie. Sociologický ústav AV ČR, Praha.

WOOD, A., VALLER, D. (2004): Governing local and regional economies: institutions, politics and economic development. Ahsgate, Aldershot.

WOOLCOCK, M. (2001): Using social capital: getting the social relations right in the theory and practice of economic development. Princeton University Press, Princeton.

ZUKAUSKAITE, E., TRIPPL, M, PLECHERO, M. (2017): Institutional thickness revisited. Economic Geography, 93, 4, 325-345.

\section{ACKNOWLEDGMENTS}

The research was funded by the Czech Science Foundation (GA ČR), project No. P410/12/G113.

\section{ORCID}

MAREK KOMÁREK

https://orcid.org/0000-0003-3365-2921

PAVEL CHROMÝ

https://orcid.org/0000-0003-3239-9514 